\title{
Development of a monoclonal antibody against viral haemorrhagic septicaemia virus (VHSV) genotype IVa
}

\author{
T. Ito ${ }^{1, *}$, N. J. Olesen ${ }^{2}$, H. F. Skall ${ }^{2}$, M. Sano ${ }^{3}$, J. Kurita ${ }^{1}$, K. Nakajima ${ }^{4}$, T. Iida ${ }^{3}$ \\ ${ }^{1}$ Tamaki Station, Aquatic Animal Health Division, National Research Institute of Aquaculture, Fisheries Research Agency, \\ Tamaki, Mie 519-0423, Japan \\ ${ }^{2}$ Section for Fish Diseases, Division of Poultry, Fish and Fur Animals, National Veterinary Institute, \\ Technical University of Denmark, Hangøvej 2, 8200 Århus N, Denmark \\ ${ }^{3}$ Aquatic Animal Health Division, National Research Institute of Aquaculture, Fisheries Research Agency, Minami-Ise, \\ Mie 516-0193, Japan
}

${ }^{4}$ Aquatic Genomics Research Center, National Research Institute of Fisheries Science, Fisheries Research Agency, Fukuura, Kanazawa, Yokohama, Kanagawa 236-8648, Japan

\begin{abstract}
The viral haemorrhagic septicaemia virus (VHSV) comprises 4 major genotypes and a number of subtypes with, in most cases, distinct geographical distribution. A quick and simple detection method that can discriminate the different genotypes is desirable for a quick and more efficient prevention of the spread of genotypes to new geographical areas. A monoclonal antibody (MAb) against VHSV genotype IVa was produced, with the aim of providing a simple method of discriminating this genotype from the other VHSV genotypes (I, II, III and IVb). Balb/c mice were injected with purified VHSV-JF00Ehil (genotype IVa) from diseased farmed Japanese flounder. Ten hybridoma clones secreting monoclonal antibodies (MAbs) against VHSV were established. One of these, MAb VHS-10, reacted only with genotype IVa in indirect fluorescent antibody technique (IFAT) and ELISA. Using cell cultures that were transfected with each of the viral protein genes, it was shown that the MAb VHS-10 recognizes a nonlinear genotype IVa-specific epitope on the VHSV N-protein.
\end{abstract}

KEY WORDS: VHSV • Genotyping $\cdot$ Monoclonal antibody $\cdot$ Indirect fluorescent antibody technique IFAT $\cdot$ ELISA

\section{INTRODUCTION}

Viral haemorrhagic septicaemia (VHS) is a serious disease of farmed rainbow trout Oncorhynchus mykiss in Europe. In the last 2 decades, the VHS virus (VHSV) has been isolated from wild marine fish in the northern hemisphere along North American, Japanese and northern European coasts. Four genotypes of VHSV with, in most cases, distinct geographical distributions have been described (Snow et al. 2004, Einer-Jensen et al. 2005, Skall et al. 2005).

In Japan, VHSV was first detected in farmed Japanese flounder Paralichthys olivaceus in 1996 (Isshiki et al. 2001). Since then, VHSV has been isolated from both farmed and wild flounder (Takano et al. 2000, Nishizawa et al. 2002). Recently, VHSV was isolated from farmed black rockfish Sebastes inermis (Isshiki et al. 2003), oblong rockfish Sebastes oblongus, Japanese jack mackerel Trachurus japonicus, red sea bream Pagrus major, and cultured and wild Pacific sandeel Ammodytes personatus (Watanabe et al. 2002, Isshiki et al. 2003). All VHSV isolates from Japan were identified as genotype IVa (Ito et al. 2004), except for 1 isolate (KRRV9601) from farmed Japanese flounder from 1996 which belongs to genotype Ib. It was suggested that VHSV genotype Ib was accidentally introduced into Japan by importation of fish or fish products from overseas (Nishizawa et al. 2002, Einer-Jensen et al. 2005). Considering the serious dis- 
ease outbreaks caused by genotype IV VHSV in North America in the last decade, the further geographical spread of this genotype is a serious risk to both the aquaculture industry and wild fish resources.

Once VHSV genotypes are introduced into new areas, they may cause severe outbreaks of VHS in susceptible fish species. According to the OIE (Office International des Epizooties/World Organisation for Animal Health) Aquatic Animal Health Code, even if the same disease agent is present in both the importing and the exporting country, the importing country can demand health certification from the exporting country for imports when the pathogenicity or host range of the strain in the exporting country is significantly higher or larger than in the importing country. In order to prevent the spread or introduction of a new VHSV genotype, issue health certificates, and implement quarantine and disease control programs, a quick and simple detection method to discriminate the different genotypes is desired.

Geno- and subtyping of VHSV isolates are usually undertaken using sequence analyses. In addition, Einer-Jensen et al. (1995) reported that VHSV genotype IV can be discriminated from the other genotypes by RT-PCR using specific primer sets for the amplification of the $\mathrm{N}$ gene fragments of the genotype. Access to other tests for VHSV typing, such as a reliable immunoassay that may be more convenient than molecular techniques, would be an improvement. Therefore, a monoclonal antibody (MAb) against a Japanese isolate of VHSV type IVa was produced in order to develop simple immunochemical methods for easy and quick discrimination between genotype IVa and the other genotypes of VHSV.

\section{MATERIALS AND METHODS}

Cell line. The fathead minnow (FHM) cell line (Gravell \& Malsberger 1965) that was used in this study was maintained in minimum essential medium (MEM; MP Biomedicals) supplemented with $10 \%$ fetal bovine serum (FBS; Gibco, Invitrogen) and antibiotics (100 units penicillin $\mathrm{ml}^{-1}$ and $100 \mu \mathrm{g}$ streptomycin $\mathrm{ml}^{-1}$ ). The cell line and the virusinfected cells were cultivated at 25 and $20^{\circ} \mathrm{C}$, respectively.

Virus. VHSV strain JF00Ehi1 from Japanese flounder (Ito et al. 2004) was concentrated and gradient-purified as described by Nishizawa et al. (1991). The purified virus was used for immunization of mice as well as for sodium dodecyl sulphate polyacrylamide gel electrophoresis (SDS-PAGE). Seventy-four VHSV isolates from around the world (Tables $1 \&$ 2) were used to characterize some of the obtained monoclonal antibodies (MAbs). Infectious hematopoietic necrosis virus (IHNV) isolated from cherry salmon Oncorhynchus masou masou in Japan (T. Ito unpubl.) and hirame rhabdovirus (HIRRV) isolated from Japanese flounder in Japan (Kimura et al. 1986) were also included as specificity controls.

Immunization of mice. Two 6 wk old Balb/c mice were injected intraperitoneally with $0.1 \mathrm{ml}$ of purified virus suspended in PBS (phosphate-buffered saline) and mixed with an equal volume of adjuvant (Ribi adjuvant system, MPL+TDM emulsion; Funakoshi). The mice were given an intravenous booster injection of purified virus suspended in PBS 6 wk after the first immunization. Three days after the booster, the mice were sacrificed and the spleens removed for fusion.

Cell fusion. Spleen cells from immunized mice were fused with P3-X63-Ag8.653 myeloma cells in 50\% polyethylene glycol 1500 (Roche). The cells were resuspended in hypoxanthine-aminopterine-thymidine (HAT)

Table 1. Japanese viral haemorrhagic septicaemia virus (VHSV) isolates that were used for the characterization of monoclonal antibodies (MAbs). All isolates were from farmed diseased fish. Virus genotype classification was based on the method of Einer-Jensen et al. (1995, 2005). NRIA FRA: National Research Institute of Aquaculture, Fisheries Research Agency, Japan

\begin{tabular}{|lcccl}
\hline Isolate & Year & Genotype & Host & \multicolumn{1}{c|}{ Source } \\
\hline KRRV9601 & 1996 & Ib & Japanese flounder & Isshiki et al. (2001) \\
KRRV9822 & 1998 & IVa & Japanese flounder & Nishizawa et al. (2002) \\
KRRV9906 & 1999 & IVa & Japanese flounder & NRIA FRA (this study) \\
KRRV0011 & 2000 & IVa & Japanese flounder & NRIA FRA (this study) \\
ORRV0007 & 2000 & IVa & Japanese flounder & NRIA FRA (this study) \\
OKRRV0020 & 2000 & IVa & Japanese flounder & NRIA FRA (this study) \\
YRRV0039 & 2000 & IVa & Japanese flounder & NRIA FRA (this study) \\
FH0102 & 2000 & IVa & Japanese flounder & NRIA FRA (this study) \\
JF00Ehi1 & 2000 & IVa & Japanese flounder & Nishizawa et al. (2002), \\
& & & & Ito et al. (2004) \\
KRRV0101 & 2001 & IVa & Japanese flounder & NRIA FRA (this study) \\
JF01Ehi1 & 2001 & IVa & Japanese flounder & NRIA FRA (this study) \\
BR01Ehi1 & 2001 & IVa & Black rockfish & NRIA FRA (this study) \\
JF01Oit1 & 2001 & IVa & Japanese flounder & NRIA FRA (this study) \\
JF01Kum1 & 2001 & IVa & Japanese flounder & NRIA FRA (this study) \\
JF01Nag1 & 2001 & IVa & Japanese flounder & NRIA FRA (this study) \\
KRRV0201 & 2002 & IVa & Japanese flounder & NRIA FRA (this study) \\
JF02Ehi1 & 2002 & IVa & Japanese flounder & NRIA FRA (this study) \\
BR02Ehi1 & 2002 & IVa & Black rockfish & NRIA FRA (this study) \\
JF02Oit1 & 2002 & IVa & Japanese flounder & NRIA FRA (this study) \\
JF02Wak1 & 2002 & IVa & Japanese flounder & NRIA FRA (this study) \\
JF02Yam1 & 2002 & IVa & Japanese flounder & NRIA FRA (this study) \\
JSL02Yam1 & 2002 & IVa & Pacific sandeel & NRIA FRA (this study) \\
JF02Nag1 & 2002 & IVa & Japanese flounder & NRIA FRA (this study) \\
JF03Wak1 & 2003 & IVa & Japanese flounder & NRIA FRA (this study) \\
\hline
\end{tabular}


Table 2. Viral haemorrhagic septicaemia virus (VHSV) isolates from around the world that were used for the characterization of monoclonal antibodies. Virus genotype classification was based on Einer-Jensen et al. (2004, 2005), Snow et al. (2004), Elsayed et al. (2006), Gagné et al. (2007), and Groocock et al. (2007). DTU Vet: National Veterinary Institute, Technical University of Denmark; Affsa: French food safety agency; SVI: State Veterinary Institute in Pulawy, Poland; VRI: Veterinary Research Institute, Brno, Czech Republic; Marine Inst.: Marine Institute, Ireland; USGS: United States Geological Survey; Pac. Biol. Stat.: Pacific Biological Station, Department of Fisheries and Oceans, Canada. Hosts are either from fresh (F), brackish (B) or sea (S) water

\begin{tabular}{|c|c|c|c|c|c|}
\hline Isolate & Country & Year & Genotype & Host & Source \\
\hline F1 & Denmark & 1962 & I & Rainbow trout $(\mathrm{F})$ & Jensen (1965) \\
\hline Hededam & Denmark & 1970 & I & Rainbow trout $(\mathrm{F})$ & Vestergård Jørgensen (1974) \\
\hline I-87 & Italy & 1969 & $\mathrm{I}^{\mathrm{a}}$ & Brown trout $(\mathrm{F})$ & DTU Vet (unpubl.) \\
\hline DK-687 & Denmark & 1973 & Ia & Rainbow trout $(F)$ & DTU Vet (unpubl.) \\
\hline DK-978 & Denmark & 1975 & Ia & Rainbow trout $(F)$ & DTU Vet (unpubl.) \\
\hline DK-3925 & Denmark & 1987 & Ia & Rainbow trout (F) & DTU Vet (unpubl.) \\
\hline DK-200098 & Denmark & 2000 & Ia & Rainbow trout (F) & Einer-Jensen et al. (2004) \\
\hline FR-02-84 & France & 1984 & Ia & Rainbow trout $(\mathrm{F})$ & Benmansour et al. (1997) \\
\hline FR-5874 & France & 1999 & Ia & Rainbow trout $(\mathrm{F})$ & Affsa (unpubl.) \\
\hline FR-403 & France & 2000 & Ia & Rainbow trout $(F)$ & Affsa (unpubl.) \\
\hline PL-201234 & Poland & 2001 & Ia & Rainbow trout (F) & DTU Vet (unpubl.) \\
\hline PL-A & Poland & 2002 & Ia & Pike fry $(F)$ & SVI (unpubl.) \\
\hline CZ-7738-R5 & Czech Republic & 1994 & Ia & Rainbow trout $(\mathrm{F})$ & DTU Vet (unpubl.) \\
\hline CAPM V553 & Czech Republic & 2000 & Ia & Rainbow trout (F) & VRI (unpubl.) \\
\hline DE-Fi13 & Germany & 1983 & Ia & Rainbow trout (F) & Schütze et al. (1999) \\
\hline $\mathrm{DE}-10 / 90$ & Germany & 1991 & Ia & Turbot (S) & Schlotfeldt et al. (1991) \\
\hline DK-M Rhabdo & Denmark & 1979 & $\mathrm{Ib}$ & $\operatorname{Cod}(\mathrm{S})$ & Jensen et al. (1979) \\
\hline $1 \mathrm{p} 8$ & Baltic Sea & 1996 & $\mathrm{Ib}$ & Herring (S) & Mortensen et al. (1999) \\
\hline SE-SVA-14 & Sweden & 1998 & $\mathrm{Ib}$ & Rainbow trout (S) & Nordblom (1998) \\
\hline SE-SVA-1033 & Sweden & 2000 & $\mathrm{Ib}$ & Rainbow trout (S) & Nordblom \& Norell (2000) \\
\hline DK-2835 & Denmark & 1982 & Ic & Rainbow trout (F) & Einer-Jensen et al. (2004) \\
\hline DK-960 & Denmark & 1975 & $\mathrm{Ic}^{\mathrm{a}}$ & Rainbow trout $(\mathrm{F})$ & DTU Vet (unpubl.) \\
\hline DK-992 & Denmark & 1975 & $\mathrm{Ic}^{\mathrm{a}}$ & Rainbow trout $(\mathrm{F})$ & DTU Vet (unpubl.) \\
\hline AU-13/95 (DK-8077) & Austria & 1995 & $\mathrm{IC}^{\mathrm{a}}$ & Rainbow trout (F) & O. Schachner (unpubl.) \\
\hline FiA01a.00 & Finland & 2000 & Id & Rainbow trout (B) & Raja-Halli et al. (2006) \\
\hline FiP02b.00 & Finland & 2000 & Id & Rainbow trout (B) & Raja-Halli et al. (2006) \\
\hline $1 \mathrm{p} 52$ & Denmark & 1996 & II & Sprat (S) & Mortensen et al. (1999) \\
\hline 4p101 & Denmark & 1996 & III & Whiting (S) & Mortensen et al. (1999) \\
\hline 4p168 & Denmark & 1996 & III & Atlantic herring (S) & Mortensen et al. (1999) \\
\hline IR-F13.02.97 & Ireland & 1997 & III & Turbot (S) & Marine Inst. Ire (unpubl.) \\
\hline L59x & France & 1987 & III & Eel $(F)$ & Castric et al. (1992) \\
\hline GH30 & Flemish Cap & 1994 & III & Greenland halibut (S) & Dopazo et al. (2002) \\
\hline Makah & USA & 1988 & IVa & Coho salmon $(\mathrm{F})$ & Brunson et al. (1989) \\
\hline KHV & USA & 1988 & IVa & Chinook salmon (F) & Hopper K (1989) \\
\hline Elliot Bay herring \#5 & USA & 1993 & IVa & Pacific herring (S) & Einer-Jensen et al. (2005) \\
\hline Minter Creek, WA & USA & 2002 & IVa & Coho salmon $(\mathrm{F})$ & USGS (unpubl.) \\
\hline Tokul Creek, WA & USA & 2006 & IVa & Steelhead $(F)$ & USGS (unpubl.) \\
\hline Port Angels, WA & USA & 2007 & IVa & Atlantic salmon (F) & USGS (unpubl.) \\
\hline $\mathrm{BC}^{\prime} 93$ & Canada & 1993 & IVa & Pacific herring (S) & Meyers \& Winton (1995) \\
\hline CAN-3624 & Canada & 1995 & IVa & Atlantic salmon (S) & $\begin{array}{l}\text { Traxler et al. (1995), } \\
\text { Pac. Biol. Stat. (unpubl.) }\end{array}$ \\
\hline BC-s-99 & Canada & 1998/99 & IVa & Sardine (S) & Hedrick et al. (2003) \\
\hline Quatsino, BC & Canada & 2002 & IVa & Sardine (S) & USGS (unpubl.) \\
\hline J-Obama 25 & Japan & 1999 & IVa & Japanese flounder (S) & Takano et al. (2000) \\
\hline JF00Ehi1 & Japan & 2000 & IVa & Japanese flounder (S) & Nishizawa et al. (2002) \\
\hline MI03GL & USA & 2003 & $\mathrm{IVb}$ & Muskellunge (F) & Elsayed et al. (2006) \\
\hline Goby 1-5 & USA & 2006 & $\mathrm{IVb}$ & Round goby $(\mathrm{F})$ & Groocock et al. (2007) \\
\hline Lake Ontario & USA & 2007 & $\mathrm{IVb}$ & Gizzard shad (F) & USGS (unpubl.) \\
\hline Budd Lake & USA & 2007 & $\mathrm{IVb}$ & Bluegill (F) & USGS (unpubl.) \\
\hline Skaneateles Lake & USA & 2007 & $\mathrm{IVb}$ & Smallmouth bass (F) & USGS (unpubl.) \\
\hline $\begin{array}{l}\text { New Brunswick } \\
\text { (CA-NB00-001) }\end{array}$ & Canada & 2000 & $\mathrm{IVb}$ & Mummichog $(\mathrm{F})$ & $\begin{array}{l}\text { Oliver (2002), } \\
\text { Gagné et al. (2007) }\end{array}$ \\
\hline
\end{tabular}

${ }^{a}$ Genotype data was generated based on the Nv gene according to the method of Einer-Jensen et al. (2005) and was provided by K. Einer-Jensen of the National Veterinary Institute, Technical University of Denmark 
medium (Dulbecco's modified Eagle's medium [DMEM; MP Biomedicals] supplemented with 10\% FBS (fetal bovine serum) and 2\% HAT supplement [Gibco, Invitrogen]) and plated in 96-well culture plates. After $12 \mathrm{~d}$ of selection in HAT medium, hybridomas producing VHSV-specific antibodies were identified by immunofluorescence assay. Cells showing positive reactions were cloned at least twice by limiting dilution in DMEM supplemented with 10\% FBS and 5\% (v/v) Briclone (Bio Research). The MAb preparations that were used in subsequent studies were unpurified cell culture supernatants from these hybridomas.

Immunoglobin (Ig) class determination. The Ig class of the MAbs was determined using a mouse monoclonal isotyping kit (AbD Serotec) according to the manufacturer's instructions.

Western blotting. SDS-PAGE was performed according to the method of Laemmli (1970) using $10 \%$ $(\mathrm{w} / \mathrm{v})$ acrylamide gels under reducing conditions. Western blotting was performed according to the principles described by Lorenzen et al. (1988). Polypeptides that were separated by SDS-PAGE were electroblotted onto a nitrocellulose membrane in a semi-dry electroblotter (Bio-Rad). As a positive control for immunostaining, specific anti-VHSV (JF00Ehi1) rabbit antiserum was used. Visualization was performed using horseradish peroxidase-conjugated antibodies and 3,3'-diaminobenzidine (in PBS) containing $0.06 \% \mathrm{H}_{2} \mathrm{O}_{2}$.

Indirect fluorescent antibody technique (IFAT) for screening of MAbs against VHSV. The binding of MAbs to infected cells was examined using IFAT. VHSV-infected and normal FHM cells on coverslips $(11 \times 40 \mathrm{~mm})$ were fixed with cold acetone for $10 \mathrm{~min}$. The coverslips were stored at $-20^{\circ} \mathrm{C}$ until used. The coverslips were then overlaid with MAbs and incubated in a humid chamber at $37^{\circ} \mathrm{C}$ for 30 min and then rinsed with PBS. Fluorescein isothiocyanate-conjugated goat anti-mouse IgG serum (MP Biomedicals) was applied and the samples were again incubated at $37^{\circ} \mathrm{C}$ for $30 \mathrm{~min}$. After another rinse, the coverslips were mounted in PBS-buffered glycerol, and examined with a fluorescence microscope.

IFAT for characterization of MAbs against VHSV. IFAT characterization of selected MAbs for their binding to the VHSV isolates (Table 2) was performed using VHSV-infected and normal epithelioma papillosum cyprini (EPC) cells (Fijan et al. 1983) in 96-well plates (Corning) after fixation with a mixture of acetone and ethanol (8:2) for $10 \mathrm{~min}$. The subsequent procedure was the same as described previously. MAb IP5B11 (Lorenzen et al. 1988) was used as a positive control.

ELISA. The reactivity of selected MAbs against a panel of VHSV (Table 2) was evaluated using doublesandwich ELISA as described by Olesen \& Jørgensen (1991), except that a mixture of protein-A purified rabbit anti G-, N- and P-protein of VHSV was used as a first layer. As a positive control, MAb IP5B11 against VHSV N-protein (Lorenzen et al. 1988) was used. This MAb has been proven to react with all known VHSV isolates (tested against $>1000$ isolates, N. J. Olesen pers. obs.).

Dot-blot analysis. The mixture of purified virus (JF00Ehi1) and SDS sample buffer (Bio-Rad) (1:1) without 2-mercaptoethanol was blotted onto a nitrocellulose membrane. This membrane was immunostained after blocking with $2 \%$ bovine serum albumin in PBS. The procedure for visualization was the same as that in Western blotting. The purified virus was used as a positive control.

Transfection. EPC cells were transfected at $25^{\circ} \mathrm{C}$ using FuGENE (Roche). Transfection was done with a purified plasmid containing pTARGET expression vectors (Promega) into which the entire amplified N, P, M or $\mathrm{G}$ gene was inserted according to the manufacturer's instructions, and tested using IFAT. The sequence of the entire genome of VHSV isolate JF00Ehi1 was registered with DDBJ/EMBL/Genbank by the authors as accession no. AB490792.

Alignments of amino acids of $\mathbf{N}$-protein. Amino acid sequences of $\mathrm{N}$-protein were obtained from DDBJ/ EMBL/Genbank. The amino acid sequences in positions 1 to 50 were aligned for this study.

\section{RESULTS}

\section{Production and screening of hybridomas}

Twelve days after fusion, $\sim 70 \%$ of the 600 seeded wells contained hybridomas. In the initial IFAT, $\sim 6 \%$ of the hybridomas reacted with VHSV-infected FHM cells and showed negative reactions with uninfected cells. Subcultivation and repeated screening using IFAT yielded 10 positive hybridoma clones, which were named VHS-1 to 10 .

\section{Ig class determination}

MAb VHS-10 belonged to the IgG2a subclass with a kappa light chain. The other 9 MAbs were determined to belong to the IgG1 subclass with a kappa light chain.

\section{Reactivity of MAbs against fish rhabdoviruses using IFAT}

Established MAbs were tested against fish novirhabdoviruses (VHSV, IHNV and HIRRV) using IFAT to determine their specificity to VHSV. All 10 MAbs specifically reacted with VHSV. 


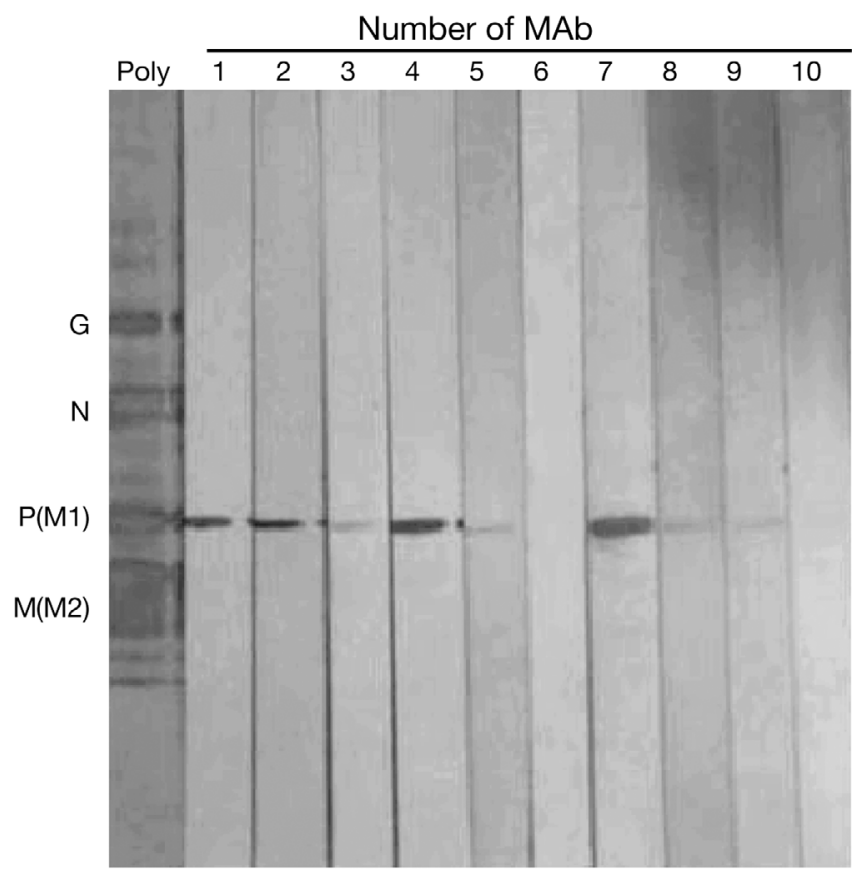

Fig. 1. Western blotting with monoclonal antibodies (MAbs) and rabbit serum against viral haemorrhagic septicaemia virus (VHSV) to analyze the antigen recognized by each MAb. The loaded antigens were purified VHSV (JF00Ehi1) virions. G: glycoprotein, N: nucleoprotein, P(M1): phosphoprotein, $\mathrm{M}(\mathrm{M} 2)$ : matrix protein

\section{Western blotting}

Western blotting results are shown in Fig. 1. Eight of the 10 MAbs recognized P-protein; however, VHS-6 and VHS-10 did not react with any virus proteins after Western blotting.

\section{Characterization of MAbs}

Four (VHS-2, $-4,-5$ and -10 ) of the 10 MAbs that were selected based on their staining intensity in IFAT against the JF00Ehi1 isolate were again tested using IFAT against the Japanese VHSV isolates given in Table 1. Three of the 4 MAbs reacted with all 24 Japanese isolates, but VHS-10 did not react with the KRRV9601 isolate that belonged to genotype Ib (Table 3). MAb VHS10 was then further characterized against the worldwide panel of VHSV given in Table 2 using IFAT and ELISA. MAb IP5B11, which was used as a positive control, reacted with all 51 isolates including all genotypes (I, Ia-d, II, III, IVa-b), while MAb VHS-10 only reacted with genotype IVa of VHSV in both IFAT and ELISA (Table 4). In IFAT, the reactivity of MAb VHS-10 against 5 selected VHSV isolates from various genotypes in infected FHM cells is shown in Fig. 2.
Table 3. Results of indirect fluorescent antibody technique (IFAT) tests of selected monoclonal antibodies (MAbs) for various viral haemorrhagic septicaemia virus (VHSV) isolates from Japan

\begin{tabular}{|c|c|c|c|c|}
\hline \multirow[t]{2}{*}{ Isolate (genotype) } & \multicolumn{4}{|c|}{ - MAb } \\
\hline & VHS-2 & VHS-4 & VHS-5 & VHS-10 \\
\hline KRRV9601(Ib) & + & + & + & - \\
\hline KRRV9822 (IVa) & + & + & + & + \\
\hline KRRV9906 (IVa) & + & + & + & + \\
\hline KRRV0011 (IVa) & + & + & + & + \\
\hline ORRV0007 (IVa) & + & + & + & + \\
\hline OKRRV0020 (IVa) & + & + & + & + \\
\hline YRRV0039 (IVa) & + & + & + & + \\
\hline FH0102 (IVa) & + & + & + & + \\
\hline JF00Ehi1 (IVa) & + & + & + & + \\
\hline KRRV0101 (IVa) & + & + & + & + \\
\hline JF01Ehi1 (IVa) & + & + & + & + \\
\hline BR01Ehi1 (IVa) & + & + & + & + \\
\hline JF01Oit1 (IVa) & + & + & + & + \\
\hline JF01Kum1 (IVa) & + & + & + & + \\
\hline JF01Nag1 (IVa) & + & + & + & + \\
\hline KRRV0201 (IVa) & + & + & + & + \\
\hline JF02Ehi1 (IVa) & + & + & + & + \\
\hline BR02Ehi1 (IVa) & + & + & + & + \\
\hline JF02Oit1 (IVa) & + & + & + & + \\
\hline JF02Wak1 (IVa) & + & + & + & + \\
\hline JF02Yam1 (IVa) & + & + & + & + \\
\hline JSL02Yam1 (IVa) & + & + & + & + \\
\hline JF02Nag1 (IVa) & + & + & + & + \\
\hline JF03Wak1 (IVa) & + & + & + & + \\
\hline
\end{tabular}

\section{Determination of the antigen recognized by $\mathrm{MAb}$ VHS-10 using transfected cell cultures}

Initially, dot-blot analysis was carried out to investigate the antigen that is recognized by VHS-10. VHS10 reacted strongly with the purified virus but not with SDS-treated virus under nonreducing conditions (data not shown), indicating recognition of a nonlinear epitope. Therefore, EPC cells were transfected to express the viral proteins N, P, M and G of the JF00Ehi1 isolate. In IFAT, the reactivity of the MAb VHS-10 against EPC cells that were transfected with pTARGET-vhs N, P, M and $\mathrm{G}$ is shown in Fig. 3. VHS-10 reacted only with EPC cells that were transfected with pTARGET-vhs N. It was thus concluded that MAb VHS-10 recognized a genotype IVa-specific epitope of the viral N-protein.

\section{Alignments of amino acids of VHSV N-protein}

Alignments of the amino acid (AA) sequences from positions 1 to 50 of the N-protein of several VHSV isolates are shown in Fig. 4. When these sequences from the N-protein of genotypes I, Ia, Ib, Ie, II, III, IVa and $\mathrm{IVb}$ were compared, unique substitutions were ob- 
Table 4. Results of indirect fluorescent antibody technique (IFAT) and ELISA tests of selected monoclonal antibodies (MAbs) for various viral haemorrhagic septicaemia virus (VHSV) isolates from around the world. For ELISA results: $(+++)>2.0$ of $\mathrm{A}_{492 i}(++)>1.2$ of $\mathrm{A}_{492 i}(+)>0.8$ of $\mathrm{A}_{492 i}(-)<0.8$ of $\mathrm{A}_{492}$

\begin{tabular}{|c|c|c|c|c|c|}
\hline \multirow[t]{2}{*}{ Genotype } & \multirow[t]{2}{*}{ Isolate } & \multicolumn{2}{|c|}{ IFAT } & \multicolumn{2}{|c|}{ ELISA } \\
\hline & & IP5B11 & VHS-10 & IP5B11 & VHS-10 \\
\hline I & F1 & + & - & +++ & - \\
\hline I & Hededam & + & - & +++ & - \\
\hline I & I-87 & + & - & +++ & - \\
\hline Ia & DK-687 & + & - & +++ & - \\
\hline Ia & DK-978 & + & - & +++ & - \\
\hline Ia & DK-3925 & + & - & +++ & - \\
\hline Ia & DK-200098 & + & - & +++ & - \\
\hline Ia & FR-02-84 & + & - & +++ & - \\
\hline Ia & FR-5874 & + & - & +++ & - \\
\hline Ia & FR-403 & + & - & +++ & - \\
\hline Ia & PL-201234 & + & - & +++ & - \\
\hline Ia & PL-A & + & - & +++ & - \\
\hline Ia & CZ-7738-R5 & + & - & +++ & - \\
\hline Ia & CAPM V553 & + & - & +++ & - \\
\hline Ia & DE-Fi 13 & + & - & +++ & - \\
\hline Ia & DE-10/90 & + & - & +++ & - \\
\hline $\mathrm{Ib}$ & DK-M Rhabdo & + & - & +++ & - \\
\hline $\mathrm{Ib}$ & $1 \mathrm{p} 8$ & + & - & +++ & - \\
\hline $\mathrm{Ib}$ & SE-SVA-14 & + & - & +++ & - \\
\hline $\mathrm{Ib}$ & SE-SVA-1033 & + & - & +++ & - \\
\hline Ic & DK-2835 & + & - & +++ & - \\
\hline Ic & DK-960 & + & - & +++ & - \\
\hline Ic & DK-992 & + & - & +++ & - \\
\hline Ic & AU-13/95 & + & - & +++ & - \\
\hline Id & FiA01a.00 & + & - & +++ & - \\
\hline Id & FiP02b.00 & + & - & +++ & - \\
\hline II & 1p52 & + & - & +++ & - \\
\hline III & $4 \mathrm{p} 101$ & + & - & +++ & - \\
\hline III & $4 \mathrm{p} 168$ & + & - & +++ & - \\
\hline III & IR-F13.02.97 & + & - & +++ & - \\
\hline III & F-L59x & + & - & +++ & - \\
\hline III & GH30 & + & - & +++ & - \\
\hline IVa & Makah & + & + & +++ & +++ \\
\hline IVa & KHV & + & + & +++ & +++ \\
\hline IVa & Elliot Bay herring \#5 & + & + & +++ & +++ \\
\hline IVa & Minter Creek, WA & + & + & +++ & +++ \\
\hline IVa & Tokul Creek, WA & + & + & +++ & +++ \\
\hline IVa & Port Angels, WA & + & + & +++ & +++ \\
\hline IVa & $\mathrm{BC}^{\prime} 93$ & + & + & +++ & +++ \\
\hline IVa & CAN-3624 & + & + & +++ & +++ \\
\hline IVa & BC-s-99 & + & + & +++ & +++ \\
\hline IVa & Quatsino, BC & + & + & +++ & +++ \\
\hline IVa & J-Obama 25 & + & + & +++ & +++ \\
\hline IVa & JF00Ehi1 & + & + & +++ & +++ \\
\hline $\mathrm{IVb}$ & MI03GL & + & - & +++ & - \\
\hline $\mathrm{IVb}$ & Goby $1-5$ & + & - & +++ & - \\
\hline $\mathrm{IVb}$ & Lake Ontario & + & - & +++ & - \\
\hline $\mathrm{IVb}$ & Budd Lake & + & - & +++ & - \\
\hline $\mathrm{IVb}$ & Skaneateles Lake & + & - & +++ & - \\
\hline $\mathrm{IVb}$ & $\begin{array}{l}\text { New Brunswick } \\
\text { (CA-NB00-001) }\end{array}$ & + & - & +++ & - \\
\hline
\end{tabular}

served at AA positions 38 (substitution of valine [V] $\rightarrow$ alanine [A]), 40 (glycine [G] or glutamic acid [E] $\rightarrow$ proline [P]) and 43 (aspartic acid [D] or glutamic acid $[\mathrm{E}]$ or alanine $[\mathrm{A}] \rightarrow$ threonine $[\mathrm{T}]$ ) in genotype IVa.

\section{DISCUSSION}

It was previously demonstrated that VHSV isolates are serologically homogeneous and that only 1 serogroup with a number of subtypes can be identified when a panel of poly- and monoclonal antibodies are used for serotyping (Olesen et al. 1993). In contrast, subsequent studies showed that VHSV isolates can be clearly discriminated into 4 major genotypes and a number of subtypes (Ia-e, II, III, and IVa-b; Snow et al. 2004, Einer-Jensen et al. 2005, Gagné et al. 2007). These genotypes appear to have geographically distinct distributions, with genotype I, II and III being found in Europe and genotype IV being found in North America and Asia.

Host range and pathogenicity appear, to some extent, to be linked to genotype (Skall et al. 2004); all rainbow trout pathogenic isolates from continental Europe thus belong to genotype Ia, while genotype Ib isolates from the North and Baltic Seas are primarily from wild marine fish and are non- or lowly virulent to rainbow trout. Within genotype IV, major differences in host range and geographical distribution are also observed. It is thus important to know the actual distribution of existing isolates and to prevent the spread of the different genotypes and subtypes of VHSV. With the development of MAb VHS-10, quick and reliable immunochemical methods can be easily implemented to discriminate the IVa from the other genotypes.

MAb IP5B11 (Lorenzen et al. 1988) reacts with all known VHSV isolates. This MAb was produced from mice that were immunized with VHSV strain F1 (genotype I) (Jensen 1965) and reacts with a linear epitope on the viral N-protein. Virus neutralizing MAbs are directed towards the viral G-protein. A 


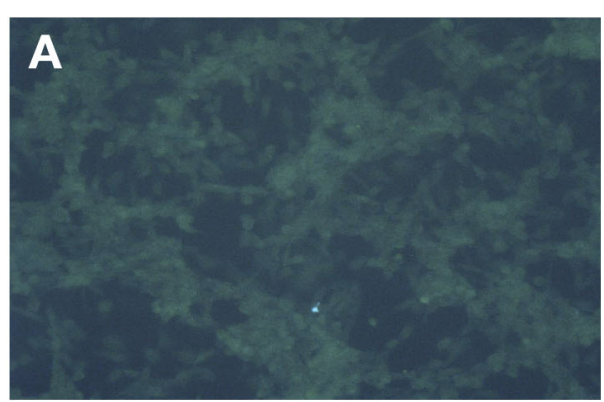

FHM cell (negative control)

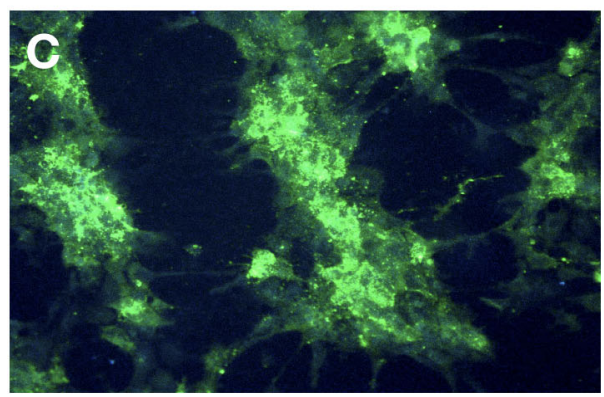

Makah (genotype IVa)

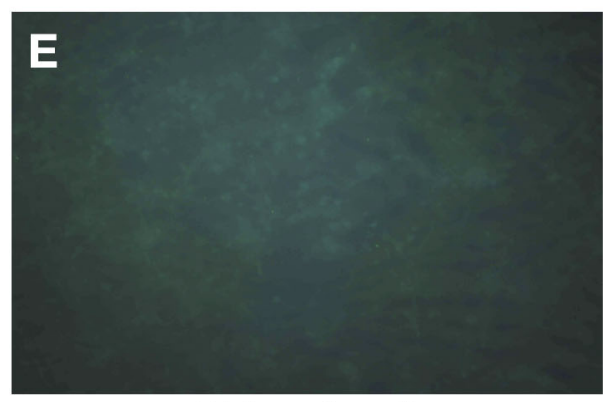

F1 (genotype I)

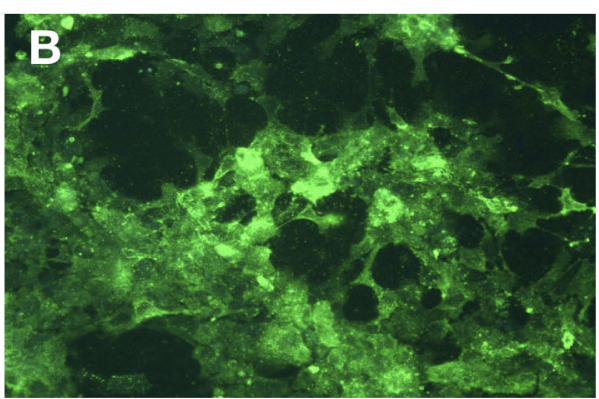

JF00Ehi1 (genotype IVa)

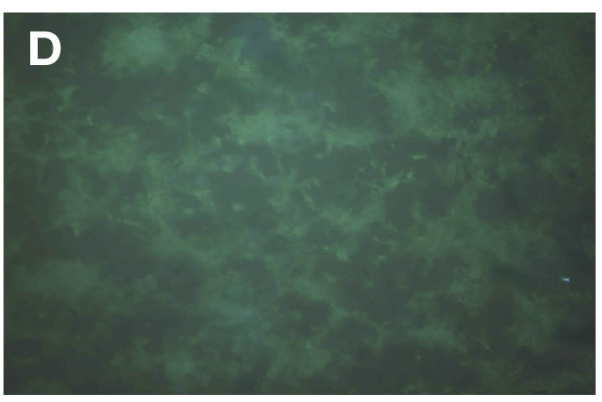

KRRV9601 (genotype lb)

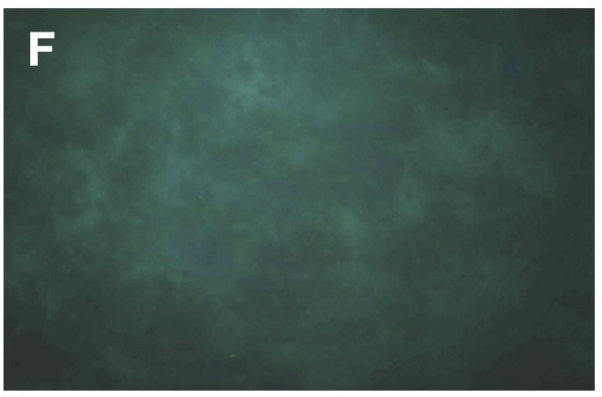

1 p52 (genotype II)

Fig. 2. Reactivity of MAb VHS-10 to virus-infected cells as assessed using indirect fluorescent antibody technique (IFAT). (A) Uninfected fathead minnow (FHM) cells, (B) JF00Ehi1-infected FHM cells, (C) Makah-infected FHM cells, (D) KRRV9601-infected FHM cells, (E) F1-infected FHM cells, (F) 1p52-infected FHM cells

panel of such virus neutralizing MAbs that was produced in VHSV F1 immunized mice (Lorenzen et al. 1990) was able to discriminate VHSV isolates into 3 serologically distinct subgroups (Olesen et al. 1993).

It was not possible to determine the protein specificity of the MAb VHS-10 as no reaction was observed during Western blotting, whether under reduced or nonreduced conditions. In ELISA, no binding of VHS10 was observed if the virus suspension was mixed with $0.1 \%$ SDS before incubation (data not shown). It was therefore anticipated that MAb VHS-10 could only recognize the 3-dimensional conformation of a viral protein. In IFAT, VHS-10 reacted strongly with EPC cells that were transfected with the $\mathrm{N}$ gene of the homologous viral isolate (JF00Ehi1), whereas no staining was observed in cells that were transfected with the $\mathrm{P}, \mathrm{M}$ or $\mathrm{G}$ genes of the same virus isolate, indicating recognition of a conformational epitope on the N-protein. Comparison of the genotype IVa deduced AA with the AA of genotypes I, II, III and IVb showed differences at the positions between AA 38 and 44 in the viral N-protein (Fig. 4.). In particular, the substitution at AA 40 (glycine [G] or glutamic acid $[\mathrm{E}] \rightarrow$ proline $[\mathrm{P}]$ ) is interesting as $\mathrm{P}$ and $\mathrm{G}$ are well known as secondary structure breakers (Colloc'h \& Cohen 1991). According to an analysis of the break point of the secondary structure in proteins using SOSUIbreaker software (http://bp.nuap.nagoya-u.ac. jp/sosui/sosuibreaker/sousuibreaker_submit.html), G does not seem to be a breaker while P is (data not shown). Therefore, this substitution might especially be related to the specificity of MAb VHS-10. It is thus most likely that VHS-10 only reacts with an epitope where the AA sequence AGPFGTD in positions 38 to 


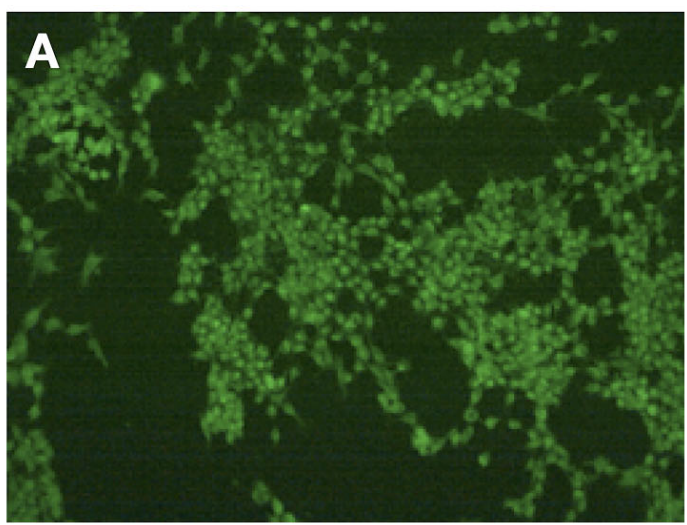

pTarget-vhsG

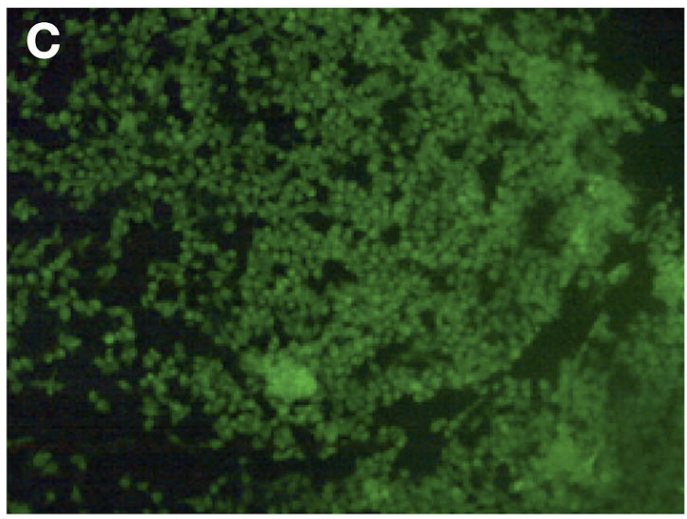

pTarget-vhsP

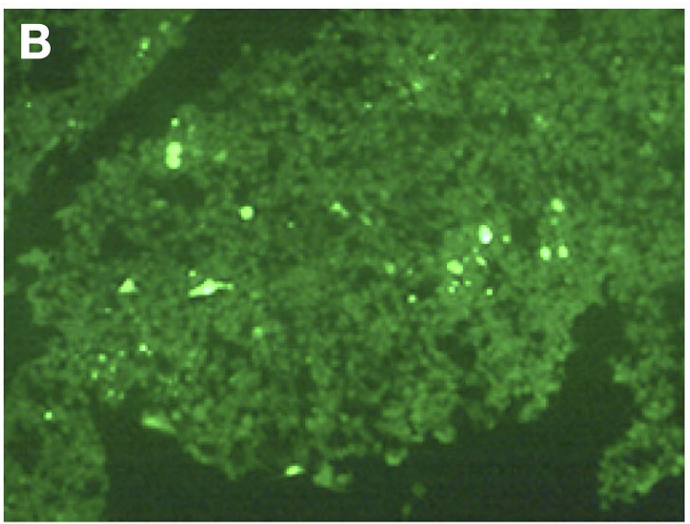

pTarget-vhsN

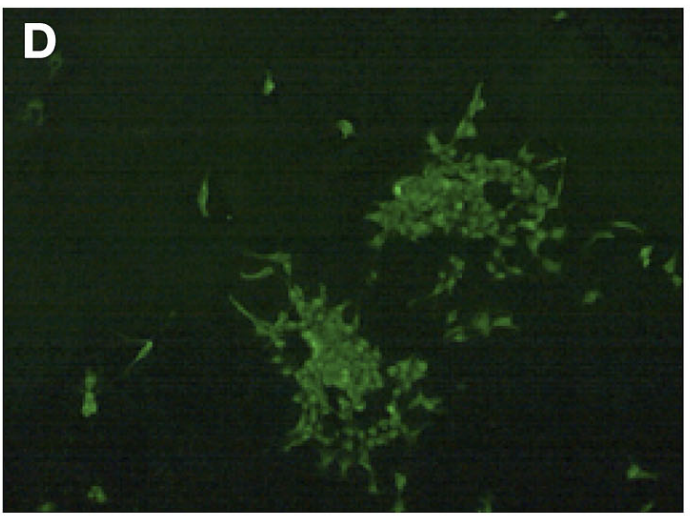

pTarget-vhsM

Fig. 3. Reactivity of MAb VHS-10 to epithelioma papillosum cyprini (EPC) cells that were transfected with the N, P, M, or G gene of viral haemorrhagic septicaemia virus (VHSV) strain JF00Ehi1 as assessed by indirect fluorescent antibody technique (IFAT). (A) G gene transfected EPC cells, (B) N gene transfected EPC cells, (C) P gene transfected EPC cells, (D) M gene transfected EPC cells

44 of the N-protein is included. By examining these AA positions in detail, one can observe that genotype III has a specific sequence with substitutions at positions AA 42 (glycine [G] $\rightarrow$ serine [S]) to 43 (aspartic acid [D] or glutamic acid [E] or threonine [T] $\rightarrow$ alanine [A]). In genotype I and Ia, AA 46 is substituted with arginine (R) or lysine (K) from glycine (G). From these findings, it can be deduced that the amino acids in positions AA 38 to 46 of the N-protein form a variable region.

The VHSV genotype IVb recently emerged in the Great Lakes region and was isolated from $>25$ different fish species during serious die-offs with high mortality rates. Since the infectivity of these isolates is very significant in many fish species (Elsayed et al. 2006, Groocock et al. 2007, Lumsden et al. 2007), there are concerns that spread to other areas may also result in significant disease outbreaks involving several fish species. In this study, VHS-10 did not react with 6 isolates of genotype IVb from different fish species in USA and Canada; it is therefore antici- pated that only IVa of genotype IV reacts with MAb VHS-10.

In recent years, genotype characteristics have been used to evaluate viral properties and molecular epidemiology of VHSV from both freshwater and marine fishes. Although genotyping is usually based on sequencing of the viral genomes, a simple method for genotyping such as IFAT or ELISA is desirable. There are so far no reports on MAbs that discriminate the different genotypes of VHSV. The study described here demonstrates the possibility of producing MAbs that recognize a specific genotype or subtype of VHSV. The establishment of monoclonal antibodies that are specific to the various genotypes and subtypes of VHSV has, therefore, been initiated in a collaborative study involving the National Research Institute of Aquaculture (Japan) as the Japanese national reference laboratory for fish diseases and the OIE reference laboratory for VHS in Denmark, with the goal of producing a panel of MAbs that would enable the quick and easy typing of VHSV isolates. 


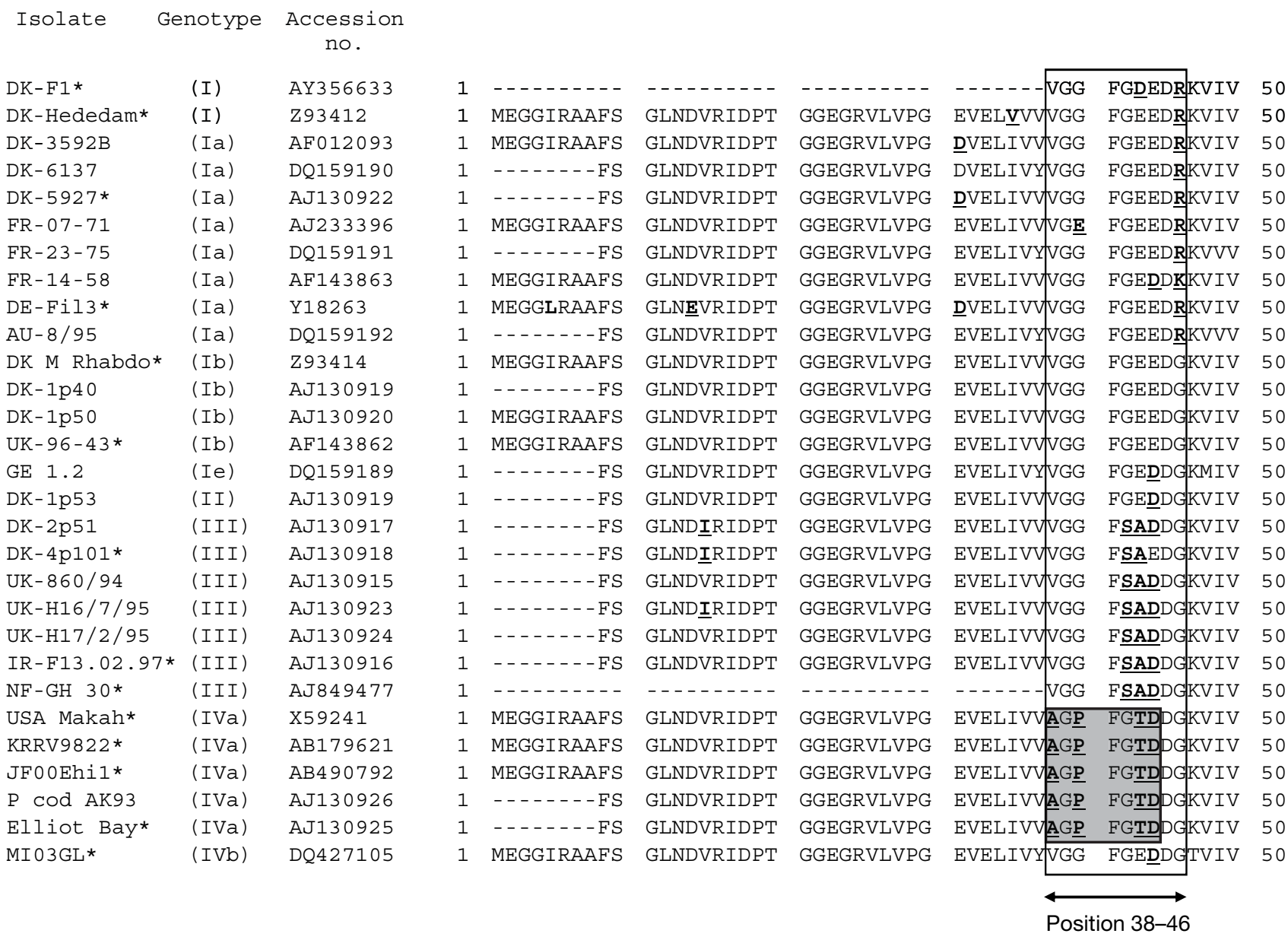

Fig. 4. Partial nucleoprotein gene (N) amino acid alignment of viral haemorrhagic septicaemia virus (VHSV) isolates. Amino acids that are shaded grey (AA 38-44 of the full $\mathrm{N}$ gene) and those that are marked with a rectangle (AA 38-46) are referred to in the 'Discussion'. $\left({ }^{*}\right)$ Virus isolates that were used for indirect fluorescent antibody technique (IFAT) and ELISA in this study as listed in Table 3

Acknowledgements. The Japanese VHSV isolates were collected through cooperation among the members of the study group of VHSV infection in Japan that consists of some local governments, Hiroshima University and National Research Institute of Aquaculture. The KRRV9601 isolate was provided by Isshiki, Mie University; the HIRRV isolate by Oseko, National Research Institute of Aquaculture; and the nonJapanese isolates from the virus library of the OIE reference laboratory for VHS, Århus, Denmark. We thank our colleagues in Europe, North America and Japan for providing the viruses in our panel, especially J. R. Winton (Western Fisheries Research Center, Seattle) and G. H. Groocock (Department of Microbiology and Immunology, College of Veterinary Medicine, Cornell University, New York) for providing the American genotype IVa and IVb isolates. We also thank all our colleagues at the National Research Institute of Aquaculture (Japan) and the National Veterinary Institute (Denmark) for their scientific and technical contribution to this study. Part of this work was undertaken while the first author was visiting the National Veterinary Institute, Technical University of Denmark as long-term researcher with an overseas fellowship from the Fisheries Research Agency. This work was mainly supported by a grant-in-aid from the Ministry of Agriculture, Forestry and Fisheries of Japan.

\section{LITERATURE CITED}

Benmansour A, Basurco B, Monnier AF, Vende P, Winton JR, de Kinkelin P (1997) Sequence variation of the glycoprotein gene identifies three distinct lineages within field isolates of viral haemorrhagic septicaemia virus, a fish rhabdovirus. J Gen Virol 78:2837-2846

Brunson R, True K, Yancey J (1989) VHS virus isolated at Makah National Fish Hatchery. Fish Health Sect Am Fish Soc Newsl 17:3-4

Castric J, Jeffroy J, Bearzotti M, de Kinkelin P (1992) Isolation of viral haemorrhagic septicaemia virus (VHSV) from wild elvers Anguilla anguilla. Bull Eur Assoc Fish Pathol 12: $21-23$

Colloc'h N, Cohen FE (1991) $\beta$-breakers: an aperiodic secondary structure. J Mol Biol 221:603-613

- Dopazo CP, Bandín I, López-Vazquez C, Lamas J, Noya M, Barja JL (2002) Isolation of viral hemorrhagic septicemia virus from Greenland halibut Reinhardtius hippoglossoides caught at the Flemish Cap. Dis Aquat Org 50: 171-179

Einer-Jensen K, Olesen NJ, Lorenzen N, Jørgensen PEV (1995) Use of the polymerase chain reaction (PCR) to differentiate serologically similar viral haemorrhagic septi- 
caemia (VHS) virus isolates from Europe and America. Vet Res 26:464-469

Einer-Jensen K, Ahrens P, Forsberg R, Lorenzen N (2004) Evolution of the fish rhabdovirus viral haemorrhagic septicaemia virus. J Gen Virol 85:1167-1179

Einer-Jensen K, Winton J, Lorenzen N (2005) Genotyping of the fish rhabdovirus, viral haemorrhagic septicaemia virus, by restriction fragment length polymorphisms. Vet Microbiol 106:167-178

Elsayed E, Faisai M, Thomas M, Whelan G, Batts W, Winton J (2006) Isolation of viral haemorrhagic septicaemia virus from muskellunge, Esox masquinongy (Mitchill), in Lake St Clair, Michigan, USA reveals a new sublineage of the North American genotype. J Fish Dis 29:611-619

Fijan N, Sulimanovic D, Bearzotti M, Muzinic D and others (1983) Some properties of the epithelioma papulosum cyprini (EPC) cell line from carp (Cyprinus carpio). Ann Inst Pasteur Vir 134:207-220

Gagné N, Mackinnon AM, Boston L, Souter B, Cook-Versloot M, Griffiths S, Oliver G (2007) Isolation of viral haemorrhagic septicaemia virus from mummichog, stickleback, striped bass, and brown trout in eastern Canada. J Fish Dis 30:213-223

Gravell M, Malsberger RG (1965) A permanent cell line from the fathead minnow (Pimephales promelas). Ann NY Acad Sci 126:555-565

Groocock GH, Getchell RG, Wooster GA, Britt KL and others (2007) Detection of viral hemorrhagic septicemia in round gobies in New York State (USA) waters of Lake Ontario and the St. Lawrence River. Dis Aquat Org 76:187-192

Hedrick RP, Batts WN, Yun S, Traxler GS, Kaufman J, Winton JR (2003) Host and geographic range extensions of the North American strain of viral hemorrhagic septicemia virus. Dis Aquat Org 55:211-220

Hopper K (1989) The isolation of VHSV from chinook salmon at Glenwood Springs, Orcas Island, Washington. Fish Health Sect Am Fish Soc Newsl 17:1-2

Isshiki T, Nishizawa T, Kobayashi T, Nagano T, Miyazaki T (2001) An outbreak of VHSV (viral hemorrhagic septicemia virus) infection in farmed Japanese flounder Paralichthys olivaceus in Japan. Dis Aquat Org 47:87-99

Isshiki T, Nagano T, Miyazaki T (2003) Susceptibility of various marine fish species to viral hemorrhagic septicemia virus isolated from Japanese flounder. Fish Pathol 38:113-115

Ito T, Mori K, Arimoto M, Nakajima K (2004) Virulence of viral hemorrhagic septicemia virus (VHSV) isolates from Japanese flounder Paralichthys olivaceus in rainbow trout and several species of marine fish. Fish Pathol 39:103-104

> Jensen MH (1965) Research on the virus of Egtved disease. Ann NY Acad Sci 126:422-426

Jensen NJ, Bloch B, Larsen JL (1979) The ulcus-syndrome in cod (Gadus morhua). III. A preliminary virological report. Nord Vet Med 31:436-442

Kimura T, Yoshimizu M, Gorie S (1986) A new rhabdovirus isolated in Japan from cultured hirame (Japanese Flounder) Paralichthys olivaceus and ayu Plecoglossus altivelis. Dis Aquat Org 1:209-217

Laemmli UK (1970) Cleavage of structural proteins during the assembly of the head of bacteriophage T4. Nature 227: $680-685$

> Lorenzen N, Olesen NJ, Jørgensen PEV (1988) Production and characterization of monoclonal antibodies to four Egtved virus structural proteins. Dis Aquat Org 4:35-42

> Lorenzen N, Olesen NJ, Jørgensen PEV (1990) Neutralization of Egtved virus pathogenicity to cell cultures and fish by monoclonal antibodies to the viral G protein. J Gen Virol 71:561-567
Lumsden JS, Morrison B, Yason C, Russell S and others (2007) Mortality event in freshwater drum Aplodinotus grunniens from Lake Ontario, Canada, associated with viral haemorrhagic septicaemia virus, type IV. Dis Aquat Org 76:99-111

> Meyers TR, Winton JR (1995) Viral hemorrhagic septicemia virus in North America. Annu Rev Fish Dis 5:3-24

- Mortensen HF, Heuer OE, Lorenzen N, Otte L, Olesen NJ (1999) Isolation of viral haemorrhagic septicaemia virus (VHSV) from wild marine fish species in the Baltic Sea, Kattegat, Skagerrak and the North Sea. Virus Res 63: 95-106

Nishizawa T, Yoshimizu M, Winton J, Ahne W, Kimura T (1991) Characterization of structural proteins of hirame rhabdovirus, HRV. Dis Aquat Org 10:167-172

Nishizawa $T$, Iida $H$, Takano $R$, Isshiki $T$, Nakajima $K$, Muroga K (2002) Genetic relatedness among Japanese, American and European isolates of viral hemorrhagic septicemia virus (VHSV) based on partial G and P genes. Dis Aquat Org 48:143-148

Nordblom B (1998) Report on an outbreak of viral haemorrhagic septicaemia in Sweden. Report for the Standing Veterinary Committee, Department for Animal Production and Health, Swedish Board of Agriculture, Jönköping

Nordblom B, Norell AW (2000) Report on an outbreak of viral haemorrhagic septicaemia in farmed fish in Sweden. Report for the Standing Veterinary Committee, Department for Animal Production and Health, Swedish Board of Agriculture, Jönköping

Olesen NJ, Jørgensen PEV (1991) Rapid detection of viral haemorrhagic septicaemia virus in fish by ELISA. J Appl Ichthyology 7:183-186

Olesen NJ, Lorenzen N, Jørgensen PEV (1993) Serological differences among isolates of viral haemorrhagic septicaemia virus detected by neutralizing monoclonal and polyclonal antibodies. Dis Aquat Org 16:163-170

Oliver G (2002) Disease interactions between wild and cultured fish-perspectives from the American Northeast (Atlantic Provinces). Bull Eur Assoc Fish Pathol 22: 103-109

Raja-Halli M, Vehmas TK, Rimaila-Pärnänen E, Sainmaa S, Skall HF, Olesen NJ, Tapiovaara H (2006) Viral haemorrhagic septicaemia (VHS) outbreaks in Finnish rainbow trout farms. Dis Aquat Org 72:201-211

Schlotfeldt HJ, Ahne W, Jørgensen PEV, Glende W (1991) Occurrence of viral haemorrhagic septicaemia in turbot (Scophthalmus maximus) - a natural outbreak. Bull Eur Assoc Fish Pathol 11:105-107

Schütze H, Mundt E, Mettenleiter TC (1999) Complete genomic sequence of viral hemorrhagic septicemia virus, a fish rhabdovirus. Virus Genes 19:59-65

> Skall HF, Slierendrecht WJ, King JA, Olesen NJ (2004) Experimental infection of rainbow trout Oncorhynchus mykiss with viral haemorrhagic septicaemia virus isolates from European marine and farmed fishes. Dis Aquat Org 58: 99-110

Skall HF, Olesen NJ, Mellergaard S (2005) Viral haemorrhagic septicaemia virus in marine fish and its implications for fish farming - a review. J Fish Dis 28:509-529

Snow M, Bain N, Black J, Taupin V and others (2004) Genetic population structure of marine viral haemorrhagic septicaemia virus (VHSV). Dis Aquat Org 61:11-21

Takano R, Nishizawa T, Arimoto M, Muroga K (2000) Isolation of viral haemorrhagic septicaemia virus (VHSV) from wild Japanese flounder Paralichthys olivaceus. Bull Eur Assoc Fish Pathol 20:186-192 
Traxler G, Kieser D, Evelyn TPT (1995) Isolation of North American strain of VHS virus from farmed Atlantic salmon. In: Margolis L (ed) Aquaculture update no. 72. Aquaculture Division, Pacific Biological Station, Nanaimo, BC

Vestergård Jørgensen PE (1974) A study of viral diseases in Danish rainbow trout, their diagnosis and control. $\mathrm{PhD}$

Editorial responsibility: Mark Crane, Geelong, Victoria, Australia thesis, Den Kongelige Veterinær- og Landbohøjskole, Copenhagen

Watanabe L, Pakingking RJ, Iida $\mathrm{H}$, Nishizawa T, Iida Y, Arimoto M, Muroga K (2002) Isolation of aquabirunavirus and viral hemorrhagic septicaemia virus (VHSV) from wild marine fishes. Fish Pathol 37:189-191

Submitted: April 21, 2009; Accepted: November 13, 2009

Proofs received from author(s): February 12, 2010 